Original Research Paper

\title{
Preliminary Studies Aimed at the Re-Opening of Pestarena Gold Mine (North-Western Alps, Italy)
}

\author{
${ }^{1}$ Andrea Giuliani, ${ }^{2}$ Giuseppe Mandrone and ${ }^{2}$ Piergiorgio Rossetti \\ ${ }^{1}$ AG3, Spin off Company of Torino University, Italy Via Valperga Caluso 35-10135 Torino, Italy \\ ${ }^{2}$ Dipartimento di Scienze della Terra, University of Torino, Italy Via Valperga Caluso 35-10135 Torino, Italy
}

\author{
Article history \\ Received: 06-06-2014 \\ Revised: 25-05-2015 \\ Accepted: 25-08-2015 \\ Correspondng Author: \\ Giuseppe Mandrone \\ Dipartimento di Scienze della \\ Terra, University of Torino, Italy \\ Via Valperga Caluso 35-10135 \\ Torino, Italy \\ Tel: ++39.011.670.51.13 \\ Email: giuseppe.mandrone@unito.it
}

\begin{abstract}
Gold, among all conventional metals subject to a progressive increase in value in the international market, has jumped powerfully into the spotlight during all economic crises. This contingency led to reconsider the dismissing process of some Italian mining sites and in particular at Pestarenain the Anzasca Valley near Macugnaga (NW Alps) -the most important historical gold mine in the Alps. This mine site interests an area of $4 \mathrm{~km}^{2}$ through about $40 \mathrm{~km}$ of tunnels. The orebodies are composed of gold-bearing post-metamorphic structures, represented by mineralized cataclasites and veins, often discontinuous and with complex structural geometry. Such a structural complexity makes it difficult to assume a profitable method of exploitation without a whole prospection of the deposit, pursuing the goals of safety and sustainability of the mine. In order to visualize the geometric relationships between orebodies and mine levels, it was necessary to digitalize the unique still existing mining plan, updated at the end of 1960 when the mine was closed. This process led to the creation of a 3D digital map. This has proven critical in the understanding of spatial relationships between surface topography and mine elements. The study allowed us to plan further field surveys based on new criteria that gave a better geo-mining knowledge of the site. It also demonstrates a potential interest for the exploitation of immediately exploitable gold resources and give interesting highlights on the possible future development of the mine activities.
\end{abstract}

Keyword: Gold Mine, 3D Model, Resource Assessment, Re-Opening, Northern Italy

\section{Introduction}

Although Italy has never been a main gold-producing country, some significant gold production occurred in the past, mainly from bedrock deposits of the Western Alpine mining district (Fig. 1).

The Pestarena mine was the most important within the district, in terms of both total gold content and production. Production dates back to the late 1600 s despite the difficulties presented by the orebody in terms of its exploitation the specifically (Zuffardi, 1997): (i) The extreme irregularity of the orebodies, (ii) the variability of the gold content (from zero to several tens $\mathrm{g} / \mathrm{t}$ ), (iii) the limited thickness of the mineralized lenses (from $30 \mathrm{~cm}$ to a little more than $1 \mathrm{~m}$ ).

For this reason, the old workings focused on exploiting the easiest (and highest-grade) portions. After the Second World War, production costs continued to grow as gold grade declined. Consequently, the mine was abandoned in 1961, leaving approximately 300,000 tons of ore at site with a gold content of at least $7 \mathrm{~g} / \mathrm{t}$. Recently, the Miniere Pestarena S.p.A has taken over the mining concession and plans to re-evaluate and potentially re-open of the mine.

To this purpose, the Dept. of Earth Sciences of Torino University has been involved with the organisation of historical data, to develop a preliminary campaign of exploration and characterization and to plan future operations in view of an exploitation of portions of the mine immediately accessible. This paper reports on the procedures which were adopted in order to attain a reasonable estimate of the "easily accessible" gold resources. Assessment of future prospects and feasibility of further mining activities is delayed to a second stage.

The re-opening of Pestarena mine could mitigate some environmental problems that today affects the Anzasca Valley. Indeed, the mine drainage waters contain some pollutants such as arsenic and the mine dumps in Ceppo Morelli village also include mercury and cyanide, resulting from the mining processes carried out in the past. 


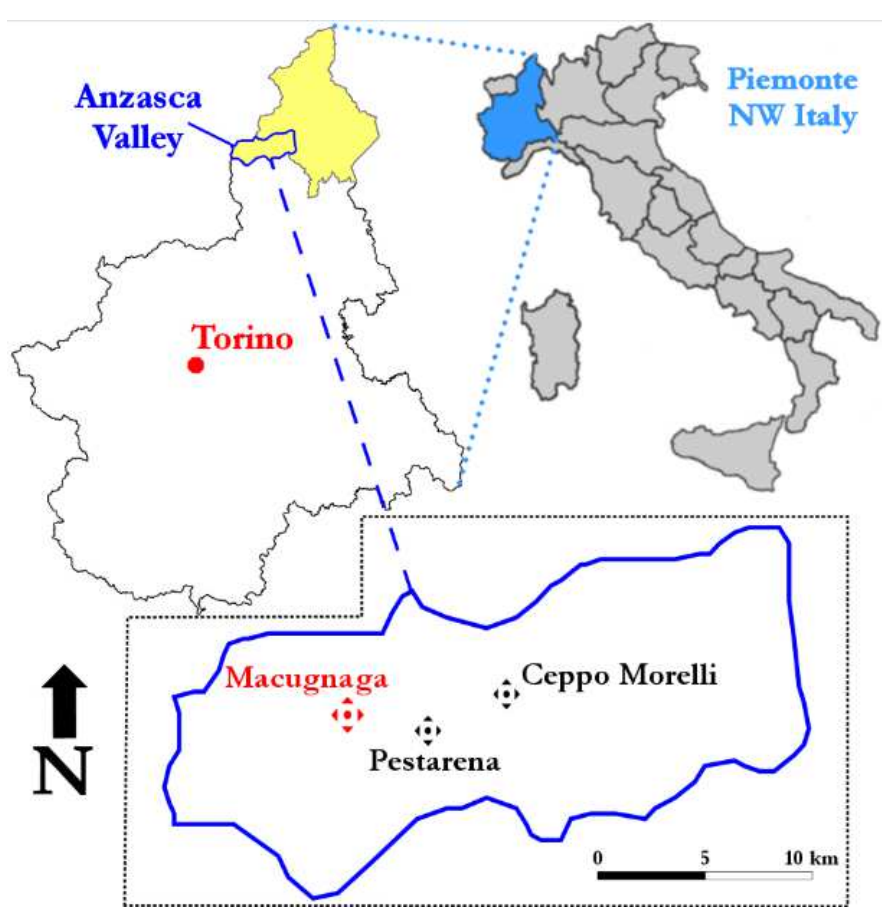

Fig. 1. Geographical framework of the Pestarena mining site

An extraction limited to the immediately exploitable panels will reduce the amount of excavation, foreseeing a limited mineral processing of the extracted material. The enriched minerals will be transported away from the mining site to be refined in a modern treatment plant.

The re-start of the exploitation works in the mining site has already helped to control dumps and the multiple accesses to underground tunnels. The relevance of tourism and environmental aspects in the Anzasca Valley will also force the mine company to pursue the overall environmental sustainability of the mining activity and, in a perspective view, a partial re-use as a museum.

\section{The Monte Rosa Gold District}

The Pestarena mining area is located in the Anzasca Valley in the north-western Alps, which are made up of a pile of complexly deformed nappes delimited by two major tectonic lineaments: The Insubric line to the east, which separates them from the southern Alpine units and the Simplon line to the north, which marks the boundary of the central Alps (Fig. 2). The Insubric line sharply divides the Alps into two blocks characterized by contrasting metamorphic histories: In fact, only the units northwest of the line record the late Cretaceous-Tertiary Alpine metamorphism. The Simplon line defines a sharp change in metamorphic grade within the area affected by the Alpine events, a consequence of differential uplift between the two blocks (Hunziker, 1970; 1974).

A number of gold-bearing vein systems, exploited for gold in the past, occur over a NE-SW trending area of about $100 \times 200 \mathrm{~km}$. As they are preferentially clustered in the Monte Rosa Unit, the term of "Monte Rosa Gold District" is often used (Leonardelli, 1986). The continental affinity Monte Rosa Unit is composed of a polymetamorphic basement intruded by late-Hercynian granitoids (transformed to orthogneisses) and of a heterogeneous lithologic sequence (Furgg Zone: Bearth, 1952) representing its Permo-Carboniferous cover. The whole Unit was affected, during alpine time, by an early eclogite-facies metamorphic event, followed by a pervasive greenschist- to amphibolite-facies overprint of Mesoalpine age (Hunziker, 1970). Some minor gold-bearing veins also occur along the Insubric line, where they are hosted by mylonitic rocks derived from the adjacent Ivrea-Verbano and Sesia-Lanzo units.

In spite of local differences mainly concerning the amount of deformation, over the whole District all deposits share strongly similar features, namely: (i) In each locality, gold occurs within quartz-carbonate gangue, filling brittle to brittle-ductile structures which postdate the alpine metamorphism and ductile deformation; (ii) associated sulphides, whose amount is highly variable, are mainly pyrite and arsenopyrite with very minor $\mathrm{Cu}-\mathrm{Pb}-\mathrm{Zn}$ sulphides; (iii) hydrothermal alteration involves sericitization and carbonatation; (iv) the available fluid inclusions data show the occurrence of ubiquitous three phases $\left(\mathrm{LH}_{2} \mathrm{O}+\mathrm{LCO}_{2}+\mathrm{V}\right)$ inclusions. These common characters allow to classify them as typical "orogenic", or "mesothermal" gold deposits (Pettke et al., 2000). 


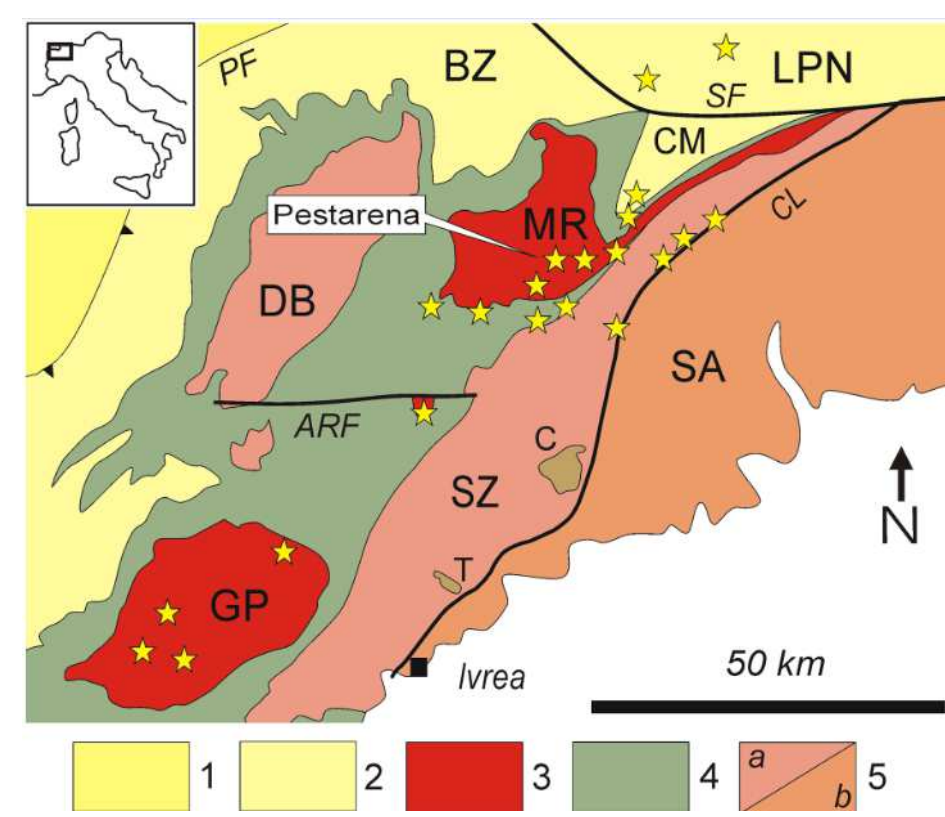

Fig. 2. Tectonic sketch-map of the north-western Alps. 1: Helvetic Domain. 2-4: Penninic Domain, 2: Briançonnais Zone 1.s. (BZ), Camughera-Moncucco Zone (CM) and Lower Pennine Nappes (LPN); 3: Internal Crystalline Massifs of Monte Rosa (MR) and Gran Paradiso (GP); 4: Piemonte Zone. 5: Austro-alpine Domain: a: Dent-Blanche nappe (DB) and Sesia Zone (SZ; intruded by the Oligocene plutons of Traversella (T) and Valle del Cervo (C)); b: Southalpine Domain (SA). CL: Canavese Line; PF: Penninic Thrust Front, SF: Simplon Fault zone, ARF: Aosta-Ranzola fault. Stars: location of the main gold-bearing veins. Modified after Labagnara et al. (2013)

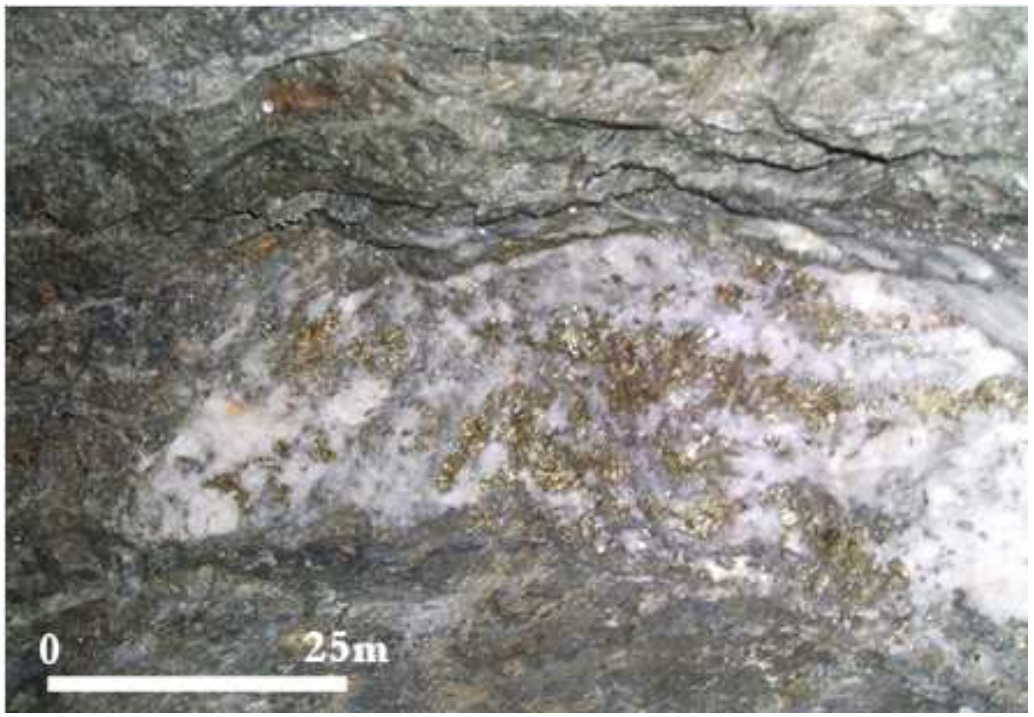

Fig. 3. Typical example of mineralized vein

Gold deposition is related to the circulation of hydrothermal fluids under mesothermal conditions (Diamond, 1990; Lattanzi, 1990). Based on geochemical and radiometric constraints, comprehensive models for the whole Monte Rosa Gold District have been developed, which involve the derivation of fluids from processes of metamorphic devolatilization during midTertiary continental collision and orogenic uplift (Curti,
1987; Pettke et al., 2000, with refs.). The liberated goldcarrying fluids ascended to form auriferous quartzcarbonate-sulphide veins (Fig. 3). These hydrothermal systems recurred over the district over a period of at least $20 \mathrm{Ma}$, their location and timing being controlled by the progress of differential uplift of the north-western Alps.; At Pestarena, gold deposition occurred at ca. $29 \mathrm{Ma}$ (Pettke et al., 1999). 


\section{Geology of the Pestarena Mine}

The mining yards of the Pestarena mine are located between 720 and $890 \mathrm{~m}$ a.s.l. on the right side of the Anzasca valley. Gold mineralization is hosted by the Monte Rosa Unit, comprising a sequence of paragneisses and mica-schists with minor amphibolites, overlain by an orthogneisses unit. The Pestarena mine is developed within the paragneisses and mica-schists, while in the adjacent Lavanchetto property, east of Pestarena, the gold mineralization occurs within the overlying orthogneisses. Depending on the host-rock lithology, the ore bodies show strongly different features: They occur along fractures and shear zones crosscutting the alpine foliation at high angle within the hard orthogneiss unit, while are sub-parallel to the foliation within the micaschists and paragneisses (Stella, 1943).

Particularly, at the Pestarena mine gold occurs along cataclastic bands and extensional veins mostly oriented WNW-ESE. Even if typical extension veins (up to few decimetres thick) locally occur, the gold mineralization is mainly related to cataclastic horizons. Gold occurs, in fact, associated with quartz and sulphides enrichment along brittle deformation planes: Orebodies are mostly represented by silicified cataclasite, composed of clasts with highly variable size (few microns to centimetres) embedded in a quartz-rich matrix. Clasts may be composed of strongly altered wall rock fragments, or of previously formed vein material, thus suggesting a multiphase brittle deformation and mineral deposition history. As a consequence, along the same structure the mineralization often occurs as a series of lens-shaped bodies, whose thickness ranges from a few centimetres to more than one meter. The sulphides content of the mineralization is variable, but generally high (up to several tens vol \%) compared to other gold deposits of the District. In the still accessible underground tunnels (Fig. 4), the mineralized structures are mostly oriented $\mathrm{N} 300-340^{\circ}$, steeply dipping north or south: Locally the same mineralized structure can change its dip direction as a consequence of late alpine open folds with very gentle WNW-ESE trending axes. Another important structural family, particularly evident on the surface, is represented by E-W, steeply dipping planes. The overall geometry of the underground exploitation galleries striking WNW-ESE with deflections in E-W direction at their ends-closely matches that expected in a dextral strike-slip, E-W trending system. Within this structural picture, the gold-rich "columns" of the mine (Bruck, 1986) probably correspond to the intersection between these two structural families.

\section{D Digitalization of Historic Mining Plans}

In last year's, three dimensional geological models have become a useful tool to better understand, share and disseminate geological information. The increasing demand of such models reflects the need of producing simulations more reliable and realistic, geometrically correct and respectful of the relations between geological bodies. Moreover, a consistent 3D geological model is the key for computations that need accurate representation (Yasitli and Unver, 2004; Jin et al., 2011; Wang and Huang, 2012; Filipello et al., 2010).

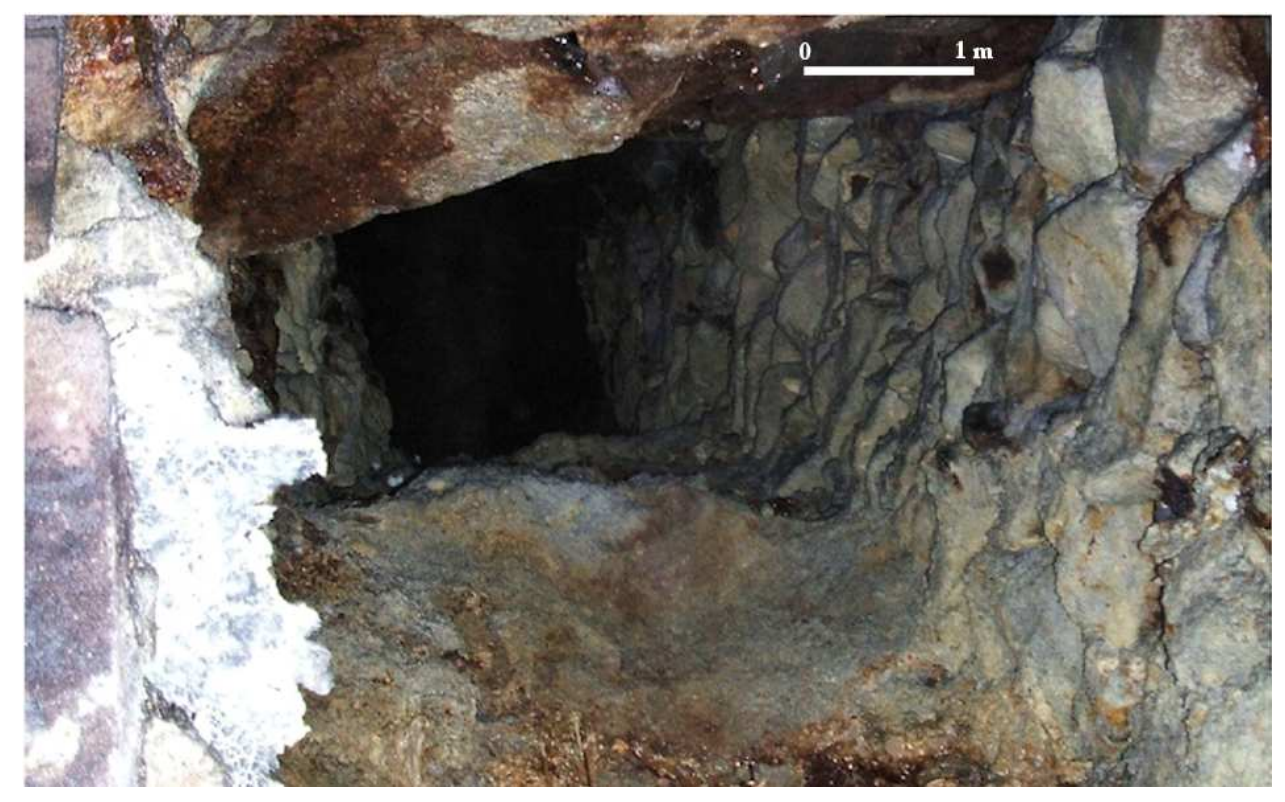

Fig. 4. Example of uplift tunnel realized into a mining fill (Courtesy of Daniele Trogolo Got) 
Therefore, this study has involved first of all the complete digitalization of geo-mining data resulting from the old exploitations at the Pestarena Mine, in order to visualize the geometric relationships that bind together the different production levels and to set up the possible future mining activities.

The process of digitalization of the historical mine plan included the following activities:

- Scanning of the huge "paper" mine plans and subsequent post-processing with computer graphics software

- Orthorectification and georeferencing (UTMWGS84 using ArcMap-ArcGIS 9.2) of the following base maps: (i) Pestarena Mine Plan (1:1,000 scale, updated 31/12/1960), (ii) Pestarena Plan Mine-second partial version (1:1,000 scale, updated 31/12/1960), (iii) Pestarena Mine - Plan of the main facilities of the master yards $(1: 1,000$ scale, updated 31/12/1960)

- Detailed digitalization of major excavation sites (with the support of higher detail sections and maps), by acquiring a large number of quoted points (approximately 30,000 points for 32 levels) along the tunnels reported in the historical documents

- Assignment of the elevation value a.s.l. for each point and planar representation of entities (polygons), useful to know the altitude of the floor of the mining levels

- Plotting of all polygons in three-dimension, with the creation of the footwall, roof and walls for each tunnel

The digital map of the Pestarena mine has been therefore implemented with the creation of the $3 \mathrm{D}$ geometrical elements for each tunnel.

After the creation of the 3D model (Fig. 5) and a preliminary control of the accessibility of the different tunnels, it was possible to schedule a preliminary prospection campaign, with the help of the new spatial information derived from the acquisition of digital data. The prospecting underground activities were focused on the recognition of the exploited and unexploited ore panels, in order to immediately identify the available resources.

Thanks to this studies, it is possible to describe actual situation of the underground mine as it follows: (i) The main haulage level, called "Morghen" (2,300 m long), is in relatively good conditions and equipped with mining electrical rail, (ii) the main decline, used as ventilation circuit and escape way, is equipped with stairs and complies with safety requirements, (iii) there are 15 main exploitation levels with a total length of about $40 \mathrm{~km}$ of tunnels, (iv) water level is at about $878 \mathrm{~m}$ a.s.l., so that eight levels are now submerged.

\section{Sampling and Analysis}

Main target of this early stage was the recognition and evaluation of the amount of "easily accessible" resources (if present) in the upper part of the mine. For this reason, during the survey activities, more than 70 samples were collected along the accessible portions of the mine. A special care was devoted to collect samples which were representative of the mineralization (i.e., avoiding selection of anomalous sulphide enrichments; chip-sampling perpendicular to the mineralized structures, etc.).

All samples were analyzed for Au using fire assay. The Au content in the analysed samples ranges from $<0.005 \mathrm{ppm}$ (i.e., below detection limit) to $120 \mathrm{ppm}$ (avg. value: $17 \mathrm{ppm}$ ). Due to the high $\mathrm{Au}$ grade variability, which is a typical feature of gold mineralizations worldwide, these data must be taken with caution: in fact, although we did our best in order to collect representative samples, such a sampling campaign cannot be considered systematic (as it would be channel sampling or core drilling). Despite this, the analytical results obtained consistent with old mining reports (Bruck, 1986).

The estimation of the amount of gold present in the deposit is not automatically connected with the amount of gold technically extractable: Current techniques for gold recovery, in fact, need that it must be "leachable", i.e., bought to solution and this does not always occur, particularly in primary deposits. It is well-known, in fact, the problem of mineralization of refractory gold, a term used to indicate that the gold mineralization is not responding positively to cyanidation. In such mineralization the degree of recovery can be much lower than $100 \%$, although it can be increased (but not always) due to pre-treatment processes such as roasting, pressure leaching or bioleaching (ref). However, the need of a pre-treatment may affect the economic viability of the deposit (Ramdohr, 1969; Petruk, 2000). The response to the passage of gold in solution depends on various factors, but especially on its microstructural position: In fact, gold is typically refractory if present as microinclusions within other minerals (particularly, typical associated sulphides like pyrite and arsenopyrite), which envelop it preventing the contact with cyanide solutions.

In order to check the microstructural position of gold in the Pestarena ore, some samples of mineralization from levels 65 and 55 (Fig. 6) were studied by microscopy i.e., under transmitted and reflected light, on polished thin sections. The microscopy study was performed on samples of both quartz veins and wall rock showing a highly variable content of sulphides. 


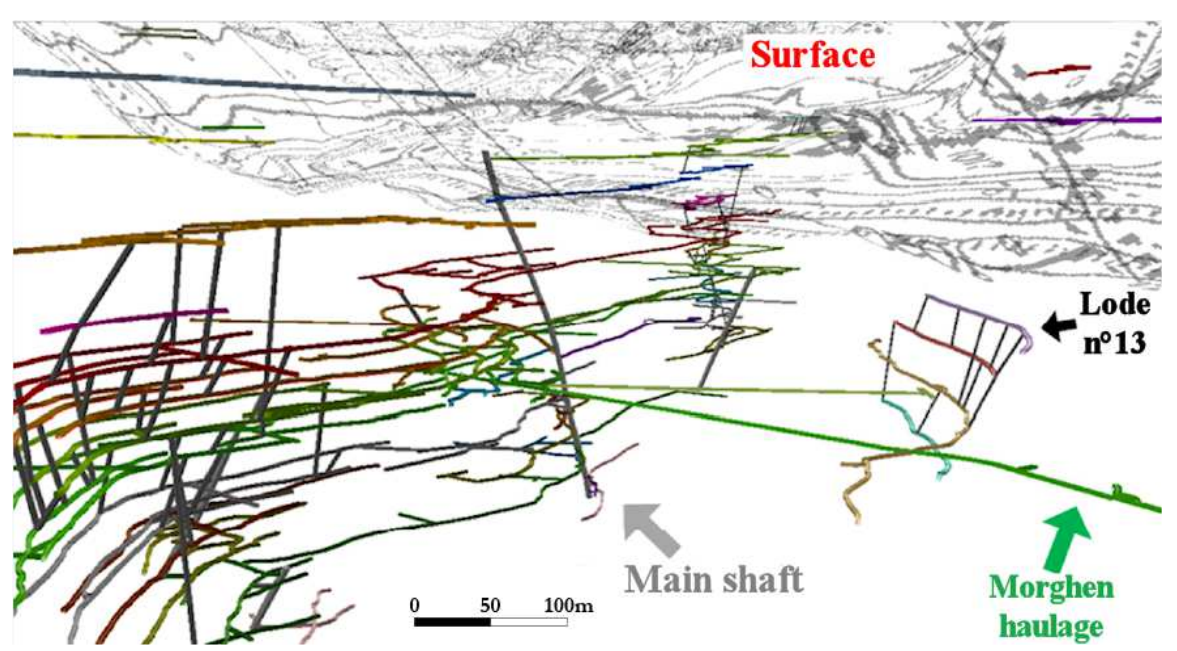

Fig. 5. 3D model reconstruction of the mine
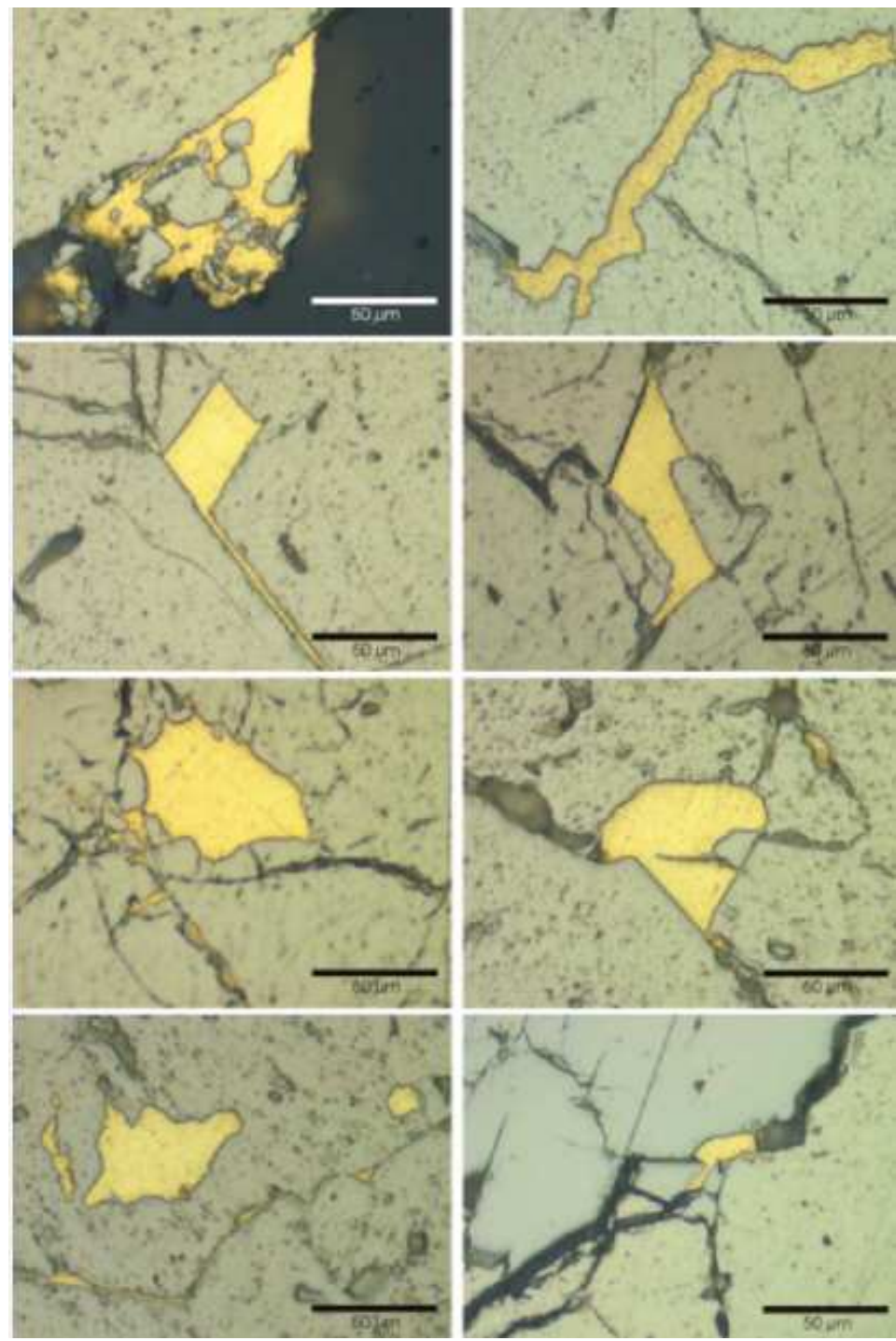

Fig. 6. Micro-photos showing the typical gold distribution in mineralized samples from the Pestarena mine 
Under the microscope abundant gold grains were detected, with highly variable size from a few to several hundred of microns. Gold invariably occurs as irregularly shaped grains closely associated with portions rich in sulphides, consisting of pyrite and arsenopyrite, with lesser amounts of chalcopyrite and galena (as typical of this type of deposits and in agreement with previous studies: e.g., Curti, 1987). Particularly, the gold grains were observed -within aggregates of sulphidesalong the contact and at the rim of sulphides grains, or along microfractures in sulphides; late gold patches cementing clasts of sulphides also occur. Grains of gold as primary microinclusions in sulphides are instead extremely rare.

These data need to be confirmed by observations on other samples (at least a few tens with homogeneous distribution in the deposit), to assume a statistical significance. However, they are in agreement with the literature data that gold at Pestarena is easily leachable, foreshadowing a high degree of recovery.

\section{Calculation of ore Extracted}

The next stage was focused on the improvement of the $2 \mathrm{D}$ and $3 \mathrm{D}$ digital modelling of the mine, for those levels interested by present geologic and mining surveys (main haulage level Morghen, Lev. 65, Lev. 55, Lev. 46, Lev. 33). Using GIS tools, sampled points were plotted and visually differentiated, by grouping the gold grades into four ranges of values ( 0 to $0.5 \mathrm{~g} / \mathrm{t} ; 0.5$ to $3 \mathrm{~g} / \mathrm{t} ; 3$ to $10 \mathrm{~g} / \mathrm{t} ;>10 \mathrm{~g} / \mathrm{t}$ ) (Fig. 7).

Along the accessible tunnels, portions of the veins already exploited in the past were identified.

The adopted procedure is summarized as follow:

- Identification and visualization, along the galleries, of the mining fills, clear evidence of past activities
- Three-dimensional digitization of the panels of past exploitations

- Estimate of the average gold grade for each panel, based on the gold content of the analysed samples, according to three different methods (see below)

- Quantification of the extracted ore for the investigated area

Step (a) has been carried out thanks to repeated surveys within the Pestarena mine. The longitudinal extension of the panels was measured by using laser rangefinder, while the developments upwards or downwards, in many cases, could be only hypothesized because it was impossible to reconstruct the real extension of the fill.

Step (b) involved the digitization of the already mined panels, in order to define exactly the borders of each element and transform each group of points in 3D polygons. This step was possible by coupling each point to its elevation: This is obtainable from the TIN of each mine-floor for points closer to this surface (red in Fig. 8), while for the others (in blue) is estimated on the height reached by the panel.

After that, these point groups, coded for each panel, were converted into $3 \mathrm{D}$ polygons (TIN), by using the external tool Geowizard ET.

The digitized points were then duplicated to set the base surface of each panel. Based on the knowledge acquired in the mine, it was assumed an average thickness for a typical orebody of $25 \mathrm{~cm}$, which was set as the distance between the roof and the bed of the same panel. The difference between the two TIN produces a shape file containing area and volume of each panel. This procedure has been carried out in a semi-automatic way for each of the investigated levels, allowing a threedimensional display of all exploited panels (Fig. 9).

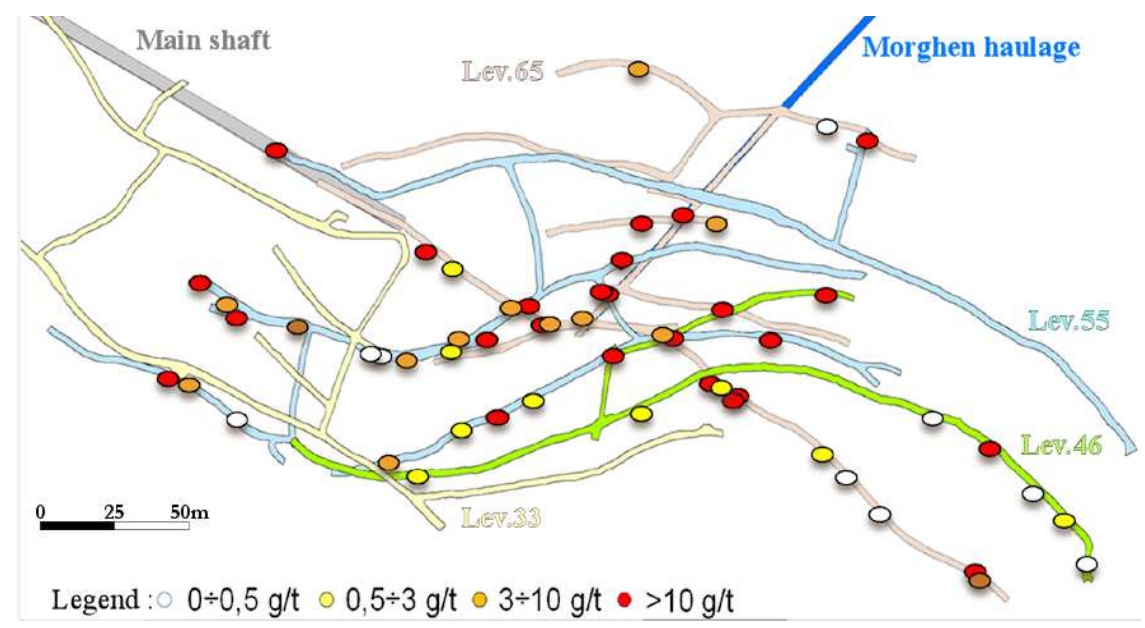

Fig. 7. 2D model of explored portions of the mine. Dots show georeferenced positioning of analysed samples from gold-bearing veins $(0 \div 0.5 \mathrm{~g} / \mathrm{t}$ : white; $0.5 \div 3 \mathrm{~g} / \mathrm{t}$ : yellow; $3 \div 10 \mathrm{~g} / \mathrm{t}$ : orange; $>10 \mathrm{~g} / \mathrm{t}:$ red $)$ 


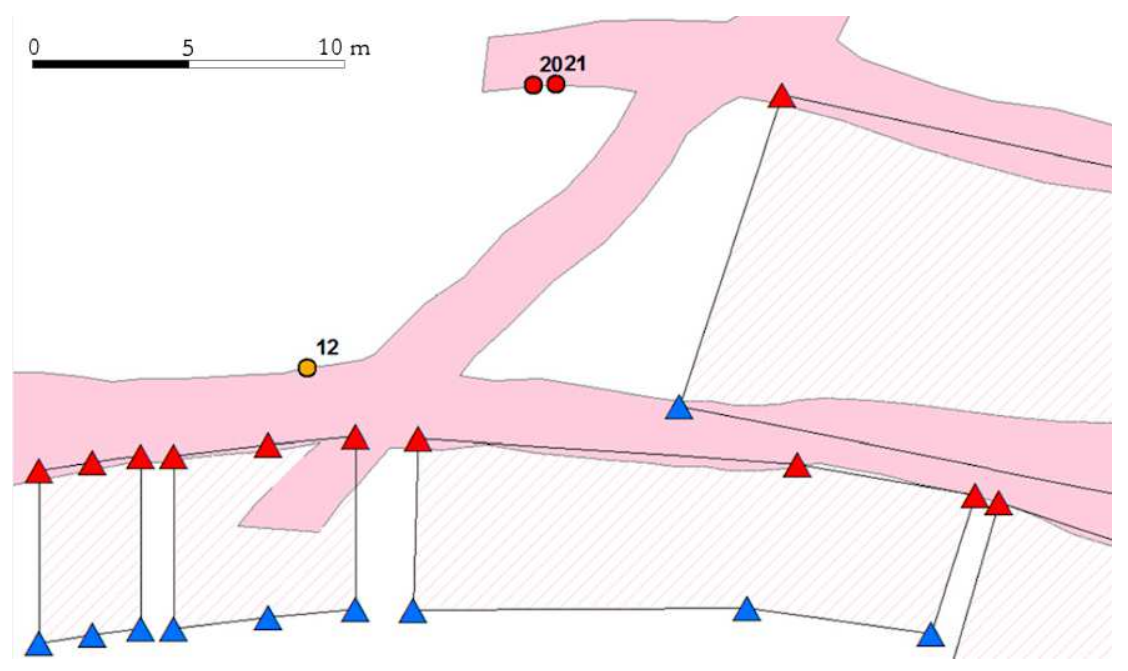

Fig. 8. Extract of some mined-out panels from level 65 and typical section of a tunnel

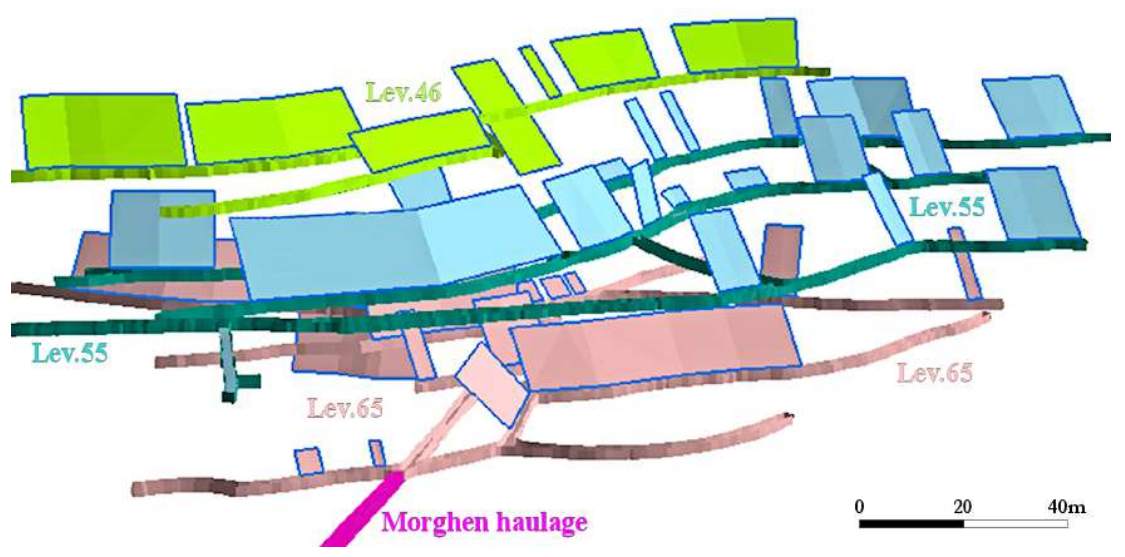

Fig. 9. Simplified three-dimensional representation of the exploited panels

Concerning step (c), the characteristics of the Pestarena mine suggest that it is not realistic to evaluate average gold content in the three investigated levels using classical geostatistical-interpolative methods like kriging, due to the extreme variation and the poor regularity of sampling. Therefore, correlation between volumes of mined panels and the consequent amount of extracted gold was carried out according to three different statistical and mathematical methods, in order to compare the obtained results. In detail, the three different methods are described as follows:

- Distributed average method- The definition of percentile allows the determination of the percentage of values below a threshold or the percentage between two thresholds. In a box plot, it is possible to view average, subdivisions in percentiles (including the median) and extreme values. Using this approach, final result turns out to be reliable because the amount of gold exploited from the ore deposit already mined is not estimated using full value, which could significantly affect the result (exploited material comes not only from the vein but also from the barren host-rock)

- Block method- It needs a preliminary subdivision of the studied levels $(65,55$ and 46) in homogeneous blocks of exploitation. Each block was coupled to samples that fall along the same gold-bearing structures, so to calculate a mean value characteristic of each block

- Centreline method- For each panel already mined out was created a barycentre line that crosses the entire element (centreline) and a buffer showing points at distances of 10 and 20 meters from it (thanks to the application of semi-automatic GIS geo-location, Fig. 10). Once analytically identified the gold content related to a single panel, a weighted average was calculated using full values within the buffer at 10 meters and half values for panels in a buffer from 10 to $20 \mathrm{~m}$ from sample site 
In order to assess the quantity of gold (in weight) it is necessary to indicate the density of the panel, mainly composed of quartz and pyrite, averaging around $2.7 \mathrm{t} / \mathrm{m}^{3}$. In this way, it was possible to estimate, using 3 different methods, the amount of gold extracted in the panels already mined out and, consequently, of the entire portion currently accessible. In some cases, the absence of samples from the already exploited panels was resolved using as a reference value - the average gold content. The areas that do not have signs of cultivation were identified and excluded from the calculation.

\section{Evaluation of Resources}

A comparison of the results of the calculation of the ore mined in the levels $65,55,46$, obtained with the different methods, is reported below (Table 1).
As shown in Table 1, values range between 88 and $127 \mathrm{~kg}$ of gold. Actually, the maximum value can be recalculated, taking also into consideration the "distributed average" method, i.e., the "arithmetic mean". In this case, by averaging the two values, it is possible to resize the gap between 88 and $109 \mathrm{~kg}$. The difference between the two methods is contained in a bit less than $25 \%$, a reasonable discrepancy considering the natural gold grade variability and the adopted sampling method.

The same methods of calculation were then applied to future possible exploitation of mining panels. The identification process was conducted directly in the mining yard, based on sample analysis.

Following the procedure listed above, 13 new ore panels were identified, belonging to levels 55 and 65 . The relatively small number of panels preliminarily identified is related to the type of mining project that must be considered as a pilot activity (Fig. 11).

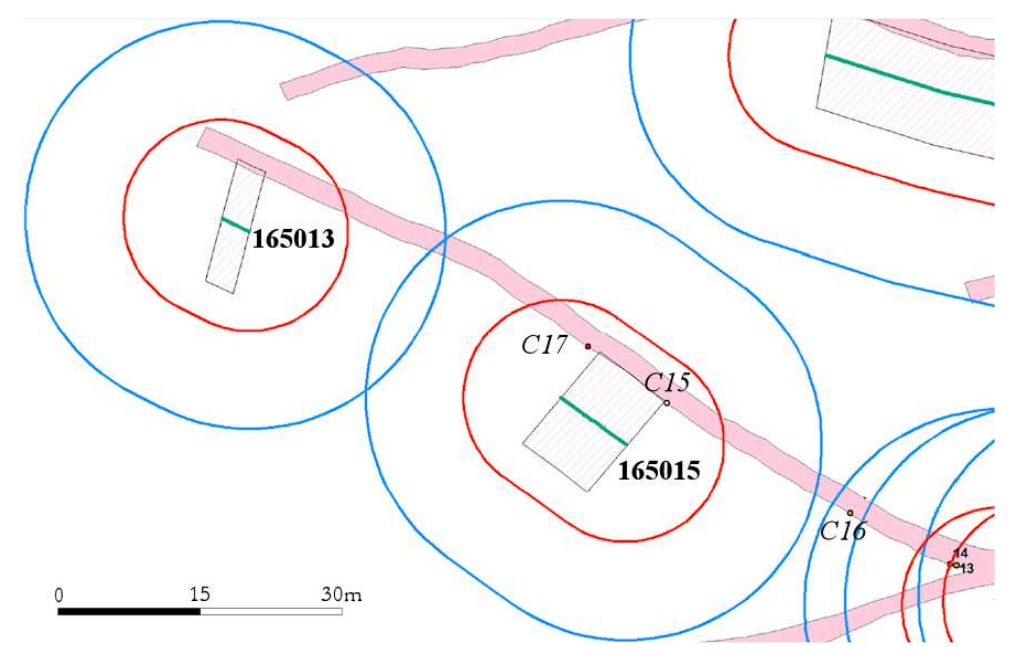

Fig. 10. Example from level 65 (pink) of two centrelines (green), with the $10 \mathrm{~m}$ (red) and $20 \mathrm{~m}$ (blue) buffers in evidence

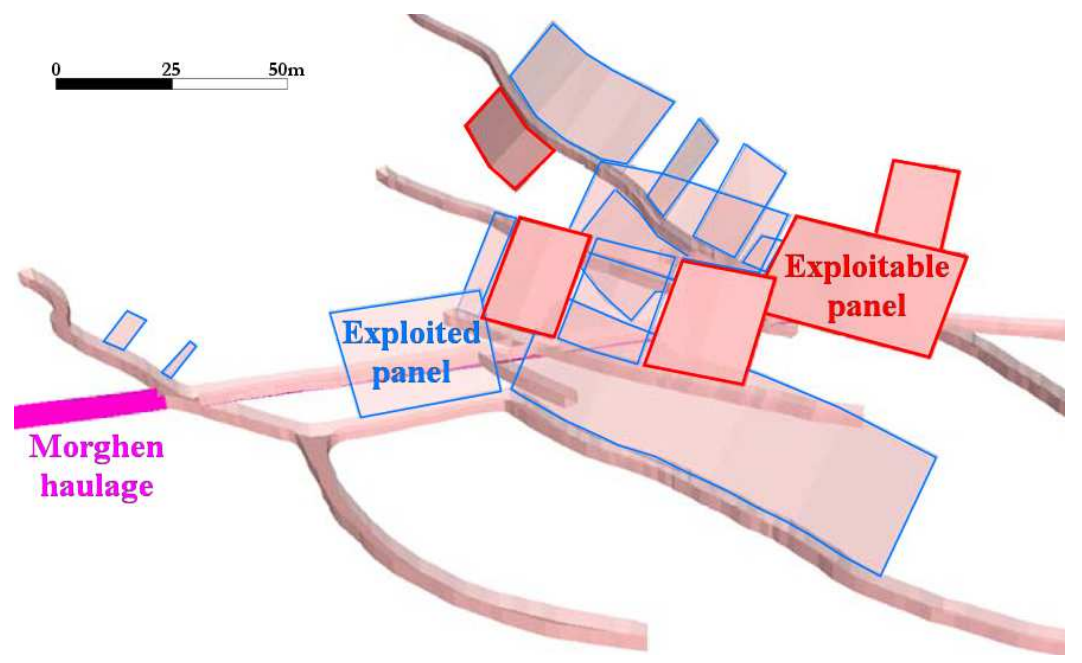

Fig. 11. Three-dimensional representation of the exploited (blue) and exploitable (red) panels of level 65 
Table 1. Comparison of the estimation of gold exploited in the past in the surveyed levels, with different calculation methods

\begin{tabular}{llll}
\hline & & Exploited panels & \\
Method & Index & Average gold content $(\mathrm{g} / \mathrm{t})$ & Gold $(\mathrm{kg})$ \\
\hline Distrib. mean & Mean & 14,00 & 91,80 \\
& Percentile 75 & 19,33 & 126,78 \\
Block & --- & 22,02 & 110,15 \\
Centreline & --- & 12,91 & 88,08 \\
\hline
\end{tabular}

Table 2. Estimation of the amount of gold still exploitable from the easily accessible portions of the Pestarena mine, with different calculation methods

\begin{tabular}{lll}
\hline & & Future \\
Method & Index & Gold $(\mathrm{kg})$ \\
\hline Distrib. mean & Mean & Average gold content $(\mathrm{g} / \mathrm{t})$ \\
& Percentile 75 & 14,20 \\
Block & --- & 14,08 \\
Centerline & --- & 23,26 \\
\hline
\end{tabular}

The results of the evaluation of the ore resources, shown in Table 2, emphasize that a gold production of at least $45 \mathrm{~kg}$ is reasonably expected from the exploitation of approximately $1,200 \mathrm{~m}^{3}$ of gold-bearing structures.

\section{Discussion}

At the end of the evaluation process, it can be stated that, in relation to the volume extracted in the recognized panels, the amount of gold is compatible with that of other contexts characterized by the same type of ore deposits, generally referred as "mesothermal", or "orogenic" gold deposits Phanerozoic in age (Misra, 2000). These deposits, in fact, typically range in grade between 5 and $15 \mathrm{~g} / \mathrm{t}$ (with peaks up to $25 \mathrm{~g} / \mathrm{t}$ : Nesbitt, 1993) and, although usually not comparable with the "giant" Archean fields, they represent an important gold source in the world. Single mines have stocks generally between one and a few tens of tons of gold, with peaks above 100 tons, as reported (Cox and Singer, 1987; Robert et al., 2007; Laznicka, 2006) for Juneau (Alaska), Mother Lode (California), Bendigo and Victoria (Australia), Macraes and Otago (New Zealand), Maiskoye and Chukotka (Russia), Salsigne (France).

The estimate of the amount of gold ore in the more accessible portions of the mine, from levels 55 and 65 , shows that the gold values resulting from the calculations performed with different approaches are comparable to each other, all supporting the interest in a re-opening of the mine. The micro-distribution of gold suggests that it is recoverable using normal techniques of leaching and that, therefore, the estimates are actually referring to gold technically extractable.

It is necessary, to emphasize that, although such an estimate is based on actual data collected in the field, the non-systematic sampling allows to perform a reasonable estimate, rather than a quantitative resource calculation. In fact one single data, regardless of the method of calculation, was associated with a larger portion of the mineralized structure. This allowed us to assess the actual presence of gold, also in interesting concentrations, but not to perform an estimate of the resources or - even more important - of the resources immediately available, complying with international reporting standards.

A systematic sampling campaign would lead to a much more accurate assessment and to more precise evaluations on the sustainability of the re-opening of this historic important mining field. A reasonable development of the research should include direct surveys (like core drilling and channel sampling) which allow a statistical analysis and a reliable estimation of available resources, important for the bankability of an industrial activity.

The real mining interest is also closely related to the logistical conditions of the mine site (accessibility of underground workings, stability of tunnels and presence of tracks in the road network): Some parts of the old mine, therefore, even if interesting in terms of gold contents, can be ruled out at this stage as located in areas not easily accessible. At the same time, the overall environmental sustainability of the mining activity in the Anzasca Valley must also be addressed.

Small scale mining of the identified panels would verify the reliability of the evaluation and to optimize both the exploitation method and the process of gold recovery. At the same time, it may also lead to the identification of additional interesting volumes. The quantitative range proposed in this study, considering an excavation of approximately $1,200 \mathrm{~m}^{3}$ of gold-bearing structures, may represent a good business opportunity, taking into account that such an initial exploitation phase should be considered as an opening phase of pilot sites.

The process of digitizing all galleries, coupled to the versatility of pre-processed spreadsheets and the use of GIS applications, allow us to manage any changes with relative rapidity. A systematic re- 
assessment of gold contents will be verified once work will start, in order to update the amount of gold still potentially extractable from this site.

\section{Conclusion}

The upgrade of the works of re-opening and securing other parts of the old mine, will allow significant improvements in the estimation of the potential resources that could be achieved (i) through the adoption of more targeted sampling techniques, (ii) by performing systematic geological surveys in the galleries and (iii) with the systematic execution of laboratory analysis focused on the treatment of gold ore.

Despite these uncertainties, the study has identified significant resources worthy of further business development.

\section{Acknowledgment}

Many thanks to Ing. Daniele Trogolo Got and Minere Pestarena srl for technical and logistic support, to Prof. Mauro Fornaro to encouraging this research, to Tara Stephens for the english revision.

\section{Author's Contributions}

The manuscript was prepared, developed and revised equally by authors.

\section{Ethics}

Miniere Pestarena srl, owners of the data, officially authorized and encouraged the publication.

\section{References}

Bearth, P., 1952. Geologie und petrographie des monte rosa. Beiträge Geologische Karte Schweiz, 96: 1-103.

Bruck, R., 1986. La miniera d'oro di Pestarena e altri giacimenti auriferi italiani. 1st Edn., Comunità Montana Valle Anzasca, pp: 189.

Cox, D. and D. Singer, 1987. Mineral Deposits Models. 1st Edn., USGS Bull. 1693, Washington, D.C., pp: 379.

Curti, E., 1987. Lead and oxygen isotope evidence for the origin of the Monte Rosa gold lode deposits (Western Alps, Italy); a comparison with Archean lode deposits. Economic Geol., 82: 2115-2140. DOI: $10.2113 /$ gsecongeo.82.8.2115

Diamond, L.W., 1990. Fluid inclusion evidence for P-V$\mathrm{T}-\mathrm{X}$ evolution of hydrothermal solutions in lateAlpine gold-quartz veins at Brusson, Val d'Ayas, Northwest Italian Alps. Am. J. Sci., 290: 912-958. DOI: $10.2475 /$ ajs.290.8.912
Filipello, A., A. Giuliani and G. Mandrone, 2010. Rock slope failure susceptibility analysis: From remote sensing measurements to geographic information system raster modules. Am. J. Environ. Sc., 6: 489-494.

Hunziker, J.C., 1970. Polymetamorphism in the Monte Rosa, Western Alps. Eclogae Geologicae HeIveticae, 63: 151-161.

Hunziker, J.C., 1974. Rb/Sr and K/Ar age determination and the Alpine tectonic history of the western Alps. Memorie dell'Istituto di Geologia e Mineralogia dell'Università di Padova, 31: 1-54.

Jin, B.X., Y.M. Fang and W.W. Song, 2011. 3D visualization model and key techniques for digital mine. Trans. Nonferrous Metals Society China, 21: 748-752. DOI: $10.1016 / \mathrm{S} 1003-6326(12) 61674-4$

Labagnara, D., M. Patrucco, P.G. Rossetti and V. Pellegrino, 2013. Predictive assessment of the asbestos content in the Western Italian Alps: An essential tool for an effective approach to risk analysis and management in tunneling operations and muck reuse. Environ. Earth Sci., 70: 857-868. DOI: $10.1007 / \mathrm{s} 12665-012-2174-1$

Lattanzi, P., 1990. The nature of the fluids associated with the Monte Rosa gold district, NW Alps, Italy. Mineralium Deposita, 25: 86-89. DOI: $10.1007 / \mathrm{BF} 00205254$

Laznicka, P., 2006. Giant Metallic Deposits: Future Sources of Industrial Metals. 1st Edn., Springer, Berlin, pp: 732.

Leonardelli, A., 1986. La provincia aurifera piemontese. Bollettino dell'Associazione Mineraria Subalpina, 23: 487-497.

Misra, K., 2000. Understanding Mineral Deposits. 1st Edn., Springer Science and Business Media, Dordrecht, ISBN-10: 0045530092, pp: 845.

Nesbitt, B.E., 1993. Phanerozoic Gold Deposits in Tectonically Active Continental Margins. In: Gold Metallogeny and Exploration, Foster, R.P. (Ed.), Chapman and Hall, London, pp: 104-132.

Petruk, W., 2000. Applied Mineralogy in the Mining Industry. 1st Edn., Elsevier, New York, ISBN-10: 0080527337, pp: 288.

Pettke, T., L.W. Diamond and I.M. Villa, 1999. Mesothermal gold veins and metamorphic devolatilization in the Northwestern Alps: The temporal link. Geology, 27: 641-644.

DOI:

$10.1130 / 0091-$ 7613(1999)027<0641:MGVAMD>2.3.CO;2

Pettke, T., A.N. Halliday, C.M. Hall and D.K. Rea, 2000. Dust production and deposition in Asia and the north Pacific Ocean over the past 12 Myr. Earth Planetary Sci. Lett., 178: 397-413. DOI: $10.1016 / \mathrm{S} 0012-821 \mathrm{X}(00) 00083-2$ 
Ramdohr, P., 1969. The Ore Minerals and their Intergrowths. 2nd Edn., Pergamon Press, Oxford, ISBN-10: 0080238017, pp: 1207.

Robert, F., R. Brommecker, B.T. Bourne, P.J. Dobak and C.J. McEwan et al., 2007. Models and exploration methods for major gold deposit types. Proceedings of 5th Decennial International Conference on Mineral Exploration, (CME' 07), pp: 691-711.

Stella, A., 1943. I giacimenti auriferi delle Alpi italiane. Memorie per descrivere la Carta Geologica d'Italia, 27: 1-134.
Yasitli, N.E. and B. Unver, 2004. 3D numerical modeling of longwall mining with top-coal caving. Int. J. Rock Mechan. Min. Sci., 42: 219-235.

DOI: 10.1016/j.ijrmms.2004.08.007

Wang, G. and L. Huang, 2012. 3D geological modeling for mineral resource assessment of the Tongshan $\mathrm{Cu}$ deposit, Heilongjiang Province, China. Geosci. Frontiers, 3 : 483-491. DOI: 10.1016/j.gsf.2011.12.012

Zuffardi, P., 1997. Considerazioni tecnico economiche sulle mineralizzazioni aurifere in Italia. Rendiconti Lincei, 8: 295-306.

DOI: $10.1007 / \mathrm{BF} 03002458$ 